\title{
Status of Chickpea Wilt caused by Fusarium oxysporum f. sp. ciceri in Marathwada Region of Maharashtra State
}

\author{
P. L. Sontakke ${ }^{1 *}$ D. N. Dhutraj ${ }^{2}$, C. V. Ambadkar ${ }^{3}$ and S. L. Badgujar ${ }^{4}$ \\ ${ }^{1}$ Badnapur 431202, India \\ ${ }^{2}$ VNMKV, ${ }^{3}$ Department of Plant Pathology, College of Agriculture, \\ ${ }^{4}$ College of Horticulture, Parbhani 431402, India \\ *Corresponding author
}

\section{A B S T R A C T}

Chickpea (Cicer arietinum L.) is one of the important rabi pulse crop grown in Marathwada region of Maharashtra state. Among various diseases, wilt caused by Fusarium oxysporum f. sp. ciceri is major devastated disease of chickpea causing losses to

Keywords

Chickpea, Survey, Wilt, Incidence, Marathwada

Article Info

Accepted:

20 June 2020

Available Online:

10 July 2020 the tune of 100 per cent in severe condition. Survey was conducted and chickpea wilt disease incidence were recorded during, the rabi seasons of 2018-19 and 2019-20, covering 150 and 162 chickpea fields, respectively from 51tahsils under 08 districts, which are distributed under three agro-climatic zones viz., scarcity zone, assured Rainfall Zone and moderately high rainfall zone of the Marathwada region of Maharashtra state. In the two cropping season the mean incidence of chickpea wilt was recorded in each district and it was found maximum in Hingoli district (33.06\%), followed by Nanded $(29.24 \%)$, Beed $(27.90 \%)$, Latur (25.12 \%), Aurangabad (24.41\%), Parbhani $(23.17 \%)$ and Jalna (22.20 $\%$ ) districts of Marathwada region,whereas, the minimum disease incidence was recorded in the Osmanabad $(21.50 \%)$ district. Present study showed that chickpea wilt is highly distributed in all the surveyed areas of Marathwada region of Maharashtra state. Variety wise incidence were recorded in Marathwada region where the average mean incidence was more on local cultivar $(46.50 \%)$ followed by BDN 9-3 (35.34 \%). However, the minimum incidence of chickpea wilt was recorded on variety Rajvijay 202 and Rajvijay 203.

\section{Introduction}

Chickpea (Cicer arietinum L.) is the world's third most important pulse widely grown in many subtropical and warm-temperate regions. In India, Chickpea was cultivated on an area of 106 lakh hectares with a production of 111 lakh tonnes and productivity of 1056 $\mathrm{kg} / \mathrm{ha}$. Total area of 20.38lakh ha was under chickpea cultivation in Maharashtra with production of 17.29 lakh tones and productivity $848.55 \mathrm{~kg} / \mathrm{ha}$ during 2019-20. In Marathwada, Chickpea was cultivated on an area of 10.59 lakh hectares with a production of 7.96 lakh tones and productivity of 707.56 $\mathrm{kg} / \mathrm{ha}$.

Amongst the several biotic and abiotic constraints responsible for low productivity of chickpea, diseases are the most serious 
constraints causing up to 100 per cent losses of crop. The crop is infected by 172 causal agents of biotic stresses, about 67 fungi, 3 bacteria, 22 viruses and 80 nematodes reported from 55 countries of the world (Nene et al., 1996).

Fusarium wilt results in major economic losses ranging from 10-40\% worldwide (Nene et al., 1984).It causes $100 \%$ loss under specific conditions (Jalali and Chand, 1992) and at particular growth stages of crop like vegetative and reproductive (Halila and Strange, 1996). The wilt caused by Fusarium oxysporum f.sp. ciceri is most devastated, widespread and important throughout the world (Gupta et al., 1997).

It infects chickpea crop with more incidence at flowering and pod forming stage, if the crop is subjected to sudden temperature rise and water stress (Chaudhry et al., 2007). In India, it is estimated that $10 \%$ yield losses were caused annually under certain conditions it may go up to $60 \%$ (Singh et al., 2007).

The incidence was varied from 14 to 32 per cent in different states as reported by Dubey et al., (2010) and 72.16 per cent as recorded by Kumar and Bourai (2012). Chickpea wilt caused by Fusarium oxysporum f. sp. ciceris is one of the important disease and causes up to $90 \%$ losses depending on weather conditions (Venkataramanamma et al., 2018). In early stage of crop wilt incidence is 7794\% whereas, late wilting 24-65\% was observed (Sunkad et al., 2019). Considering the losses caused by wilt disease of chickpea, the present study was undertaken to study the present status of chickpea wilt in Marathwada region of Maharashtra state.

\section{Materials and Methods}

A roving survey of farmers chickpea fields was conducted in the agro-climatic zones of
Marathwada region of Maharashtra state during Rabi 2018-19 and 2019-20, to estimate disease incidence and collection of chickpea plants infected with wilt caused by Fusarium oxysporum f. sp. ciceri. Chickpea growing areas were identified from the records available at the office of Sub-Divisional Agriculture Officers of the respective districts. Roving survey was undertaken during the months of December to January when the chickpea crop was at various stages of growth such as flowering and pod formation and pod development stage.

For this purpose, chickpea growing areas of all the eight districts of Marathwada were surveyed. From the chickpea cropped fields surveyed, total number of chickpea plants / two rows was counted, of which wilt suspected plants were counted separately to calculate per cent wilt incidence. About five wilted chickpea plants / field were carefully uprooted, collected in paper bags, labelled with details and brought to the laboratory for further studies. During survey, various kinds of symptoms expressed by wilted chickpea crop plants were recorded. Based on numerical data obtained in respect of total number of chickpea plants and wilted plants per field surveyed, per cent wilt incidence was calculated by applying following formula as suggested by Mayee and Datar(1986).

Total number of wilted plants

Wilt incidence $(\%)=$

Total number of plants observed

\section{Results and Discussion}

The survey on incidence of chickpea wilt was carried out from eight districts of Marathwada region of Maharashtra state with geographical area covered three agro-climatic zones, 150 and 160 chickpea crop fields, during Rabi 2018-19 and 2019-20 seasons. 
District wise Chickpea wilt incidence in Agro climatic zones of Marathwada region of Maharashtra

Results presented in Table 1 revealed that maximum average chickpea wilt incidence during Rabi 2018-19 and 2019-20 were found in Hingoli (34.12 and $32.00 \%$ ) followed by Beed (29.12 and 26.67\%), Nanded (29.03 and $29.44 \%$ ), Latur (23.92 and $26.31 \%$ ), Aurangabad (22.32 and $26.49 \%$ ), Parbhani (20.77 and $25.56 \%$ ), Osmanabad (20.71 and $22.28 \%$ ) and Jalna (20.48 and $23.92 \%$ ), respectively. The overall average of both the years indicated that the highest disease incidence was recorded in Hingoli district $(33.06 \%)$, whereas, minimum disease incidence was recorded in Osmanabad district $(21.50 \%)$.

The pooled mean (Rabi, 2018-19 and 201920) results (Fig. 1) revealed that maximum mean per cent incidence of chickpea wilt was recorded in Hingoli district (33.06\%), followed by Nanded (29.24\%), Beed (27.90 $\%)$, Latur (25.12\%), Aurangabad (24.41\%), Parbhani (23.17 \%) and Jalna (22.20 \%) districts of Marathwada region, whereas, the minimum disease incidence was recorded in the Osmanabad $(21.50 \%)$ district.

Table.1 District wise survey of Chickpea wilt incidence in Agro climatic zones of Marathwada region during Rabi 2018-2019 and Rabi 2019-2020

\begin{tabular}{|c|l|c|c|c|c|c|}
\hline $\begin{array}{c}\text { Sr. } \\
\text { No. }\end{array}$ & \multicolumn{1}{|c|}{ District } & \multicolumn{2}{|c|}{ No. of Location } & \multicolumn{2}{|c|}{$\begin{array}{c}\text { Avg. Disease Incidence } \\
\text { (per cent) }\end{array}$} & $\begin{array}{c}\text { Mean } \\
\text { Per cent disease } \\
\text { Incidence }\end{array}$ \\
\hline & & $\mathbf{2 0 1 8 - 1 9}$ & $\mathbf{2 0 1 9 - 2 0}$ & $\mathbf{2 0 1 8 - 1 9}$ & $\mathbf{2 0 1 9 - 2 0}$ & 24.41 \\
\hline $\mathbf{1}$ & Aurangabad & 24 & 31 & 22.32 & 26.49 & 22.20 \\
\hline $\mathbf{2}$ & Jalna & 23 & 24 & 20.48 & 23.92 & 23.17 \\
\hline $\mathbf{3}$ & Parbhani & 26 & 26 & 20.77 & 25.56 & 33.06 \\
\hline $\mathbf{4}$ & Hingoli & 18 & 19 & 34.12 & 32.00 & 29.24 \\
\hline $\mathbf{5}$ & Nanded & 14 & 13 & 29.03 & 29.44 & 25.12 \\
\hline $\mathbf{6}$ & Latur & 10 & 11 & 23.92 & 26.31 & 21.50 \\
\hline $\mathbf{7}$ & Osmanabad & 16 & 15 & 20.71 & 22.28 & 2.90 \\
\hline $\mathbf{8}$ & Beed & 19 & 21 & 29.12 & 26.67 & $\mathbf{2 5 . 8 3}$ \\
\hline Grand Mean & $\mathbf{1 5 0}$ & $\mathbf{1 6 0}$ & $\mathbf{2 5 . 0 6}$ & $\mathbf{2 6 . 5 8}$ & \\
\hline
\end{tabular}

Table.2 Agro-climatic zone wise disease incidence of chickpea wilt in Marathwada region of Maharashtra state during Rabi 2018-19 and Rabi 2019-2020

\begin{tabular}{|c|c|c|c|c|c|c|}
\hline \multirow{2}{*}{$\begin{array}{l}\text { Sr. } \\
\text { No. }\end{array}$} & \multirow[t]{2}{*}{ Agro-climatic Zone } & \multicolumn{2}{|c|}{ Rabi2018-19 } & \multicolumn{2}{|c|}{ Rabi 2019-20 } & \multirow{2}{*}{$\begin{array}{l}\text { Mean Per } \\
\text { cent disease } \\
\text { Incidence }\end{array}$} \\
\hline & & $\begin{array}{l}\text { No. of } \\
\text { Location }\end{array}$ & $\begin{array}{c}\text { Per } \\
\text { centdisease } \\
\text { Incidence }\end{array}$ & $\begin{array}{c}\text { No. of } \\
\text { Location }\end{array}$ & $\begin{array}{c}\text { Per cent } \\
\text { disease } \\
\text { Incidence }\end{array}$ & \\
\hline 1 & Scarcity zone & 18 & 19.36 & 20 & 22.11 & 20.74 \\
\hline 2 & $\begin{array}{l}\text { Assured rainfall } \\
\text { Zone }\end{array}$ & 110 & 25.12 & 118 & 26.18 & 25.65 \\
\hline 3 & $\begin{array}{l}\text { Moderate rainfall } \\
\text { Zone }\end{array}$ & 22 & 29.28 & 22 & 30.60 & 29.94 \\
\hline \multicolumn{2}{|c|}{ Over all mean of region } & 150 & 24.59 & 162 & 26.30 & 25.44 \\
\hline
\end{tabular}


Table.3 Variety wise incidence of Chickpea wilt in agro climatic zones of Marathwada region during Rabi 2018-19 and Rabi 2019-20

\begin{tabular}{|c|c|c|c|c|c|c|}
\hline \multirow[t]{2}{*}{$\begin{array}{l}\text { Sr. } \\
\text { No. }\end{array}$} & \multirow[t]{2}{*}{$\begin{array}{l}\text { Chickpea } \\
\text { Varieties }\end{array}$} & \multicolumn{2}{|c|}{ No. of Location } & \multicolumn{2}{|c|}{$\begin{array}{l}\text { Avg. disease Incidence } \\
\text { (per cent) }\end{array}$} & \multirow{2}{*}{$\begin{array}{c}\text { Mean } \\
\text { Per cent } \\
\text { Incidence }\end{array}$} \\
\hline & & 2018-19 & 2019-20 & 2018-19 & 2019-20 & \\
\hline 1 & BDNG 797 & 20 & 12 & 17.90 & 18.58 & 18.24 \\
\hline 2 & BDN 9-3 & 5 & 6 & 34.00 & 36.67 & 35.34 \\
\hline 3 & Vijay & 18 & 10 & 20.56 & 19.30 & 19.93 \\
\hline 4 & Vishal & 11 & 11 & 21.55 & 20.09 & 20.82 \\
\hline 5 & Digvijay & 15 & 11 & 22.73 & 19.27 & 21.00 \\
\hline 6 & Phule G 12 & 8 & 5 & 26.88 & 19.00 & 22.94 \\
\hline 7 & JAKI 9218 & 20 & 20 & 32.00 & 21.25 & 26.63 \\
\hline 8 & Rajvijay 202 & 8 & 6 & 11.88 & 09.33 & 10.61 \\
\hline 9 & Rajvijay 203 & 6 & 6 & 11.33 & 11.67 & 11.50 \\
\hline 10 & Vishwas & 6 & 4 & 36.25 & 18.75 & 27.50 \\
\hline 11 & SAKI 9516 & 4 & 6 & 32.50 & 20.83 & 26.67 \\
\hline 12 & PhuleVikram & 8 & 4 & 17.75 & 19.00 & 18.38 \\
\hline 13 & Local & 4 & 5 & 49.00 & 44.00 & 46.50 \\
\hline 14 & BDNGK 798 & 5 & 5 & 23.10 & 14.00 & 18.55 \\
\hline 15 & Virat & 10 & 5 & 22.60 & 22.60 & 22.60 \\
\hline 16 & PKVKabuli 2 & 5 & 4 & 25.75 & 17.50 & 21.63 \\
\hline 17 & Krupa & 4 & 6 & 23.67 & 16.33 & 20.00 \\
\hline 18 & Dolar & 6 & 8 & 24.30 & 16.25 & 20.28 \\
\hline \multicolumn{2}{|c|}{ Grand Mean } & 167 & 134 & 24.65 & 19.42 & 22.31 \\
\hline
\end{tabular}

Fig.1 District wise survey of Chickpea wilt incidence in Agro climatic zones of Marathwada region during Rabi 2018-2019 and Rabi 2019-2020

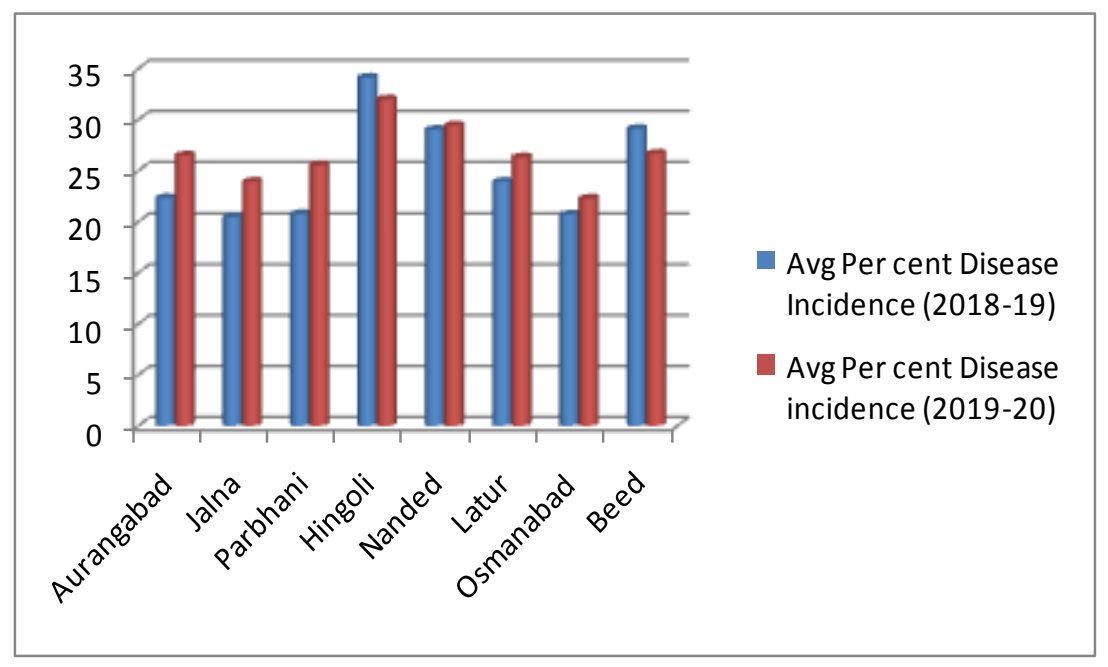


Fig.2 Agro-climatic zone wise disease incidence of chickpea wilt in Marathwada region

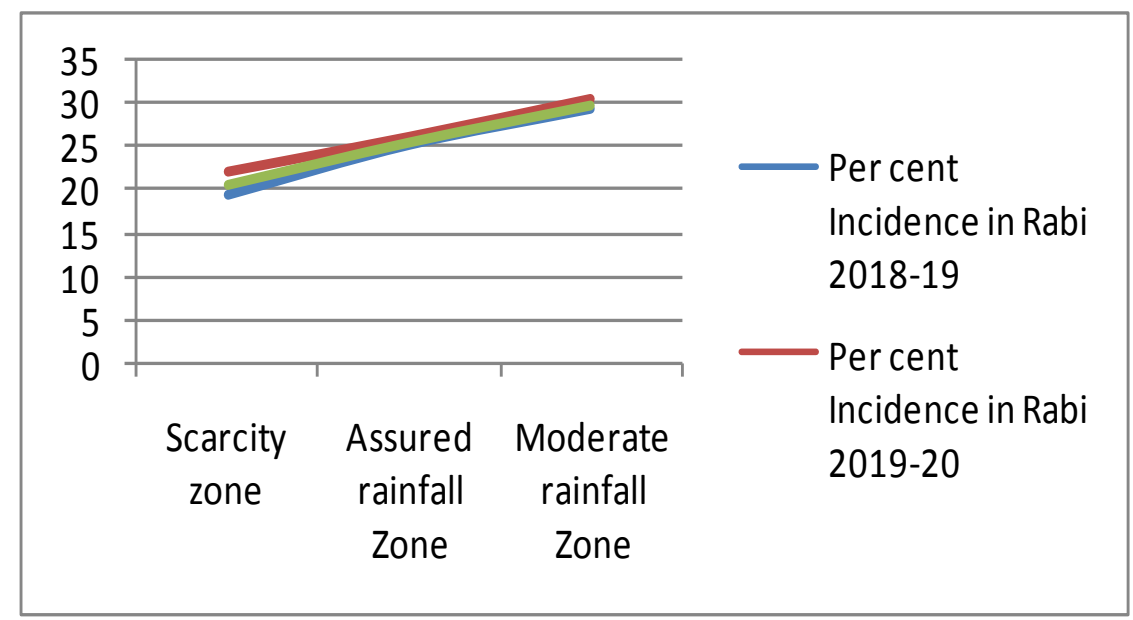

Fig.3 Variety wise incidence of Chickpea wilt in agro climatic zones of Marathwada

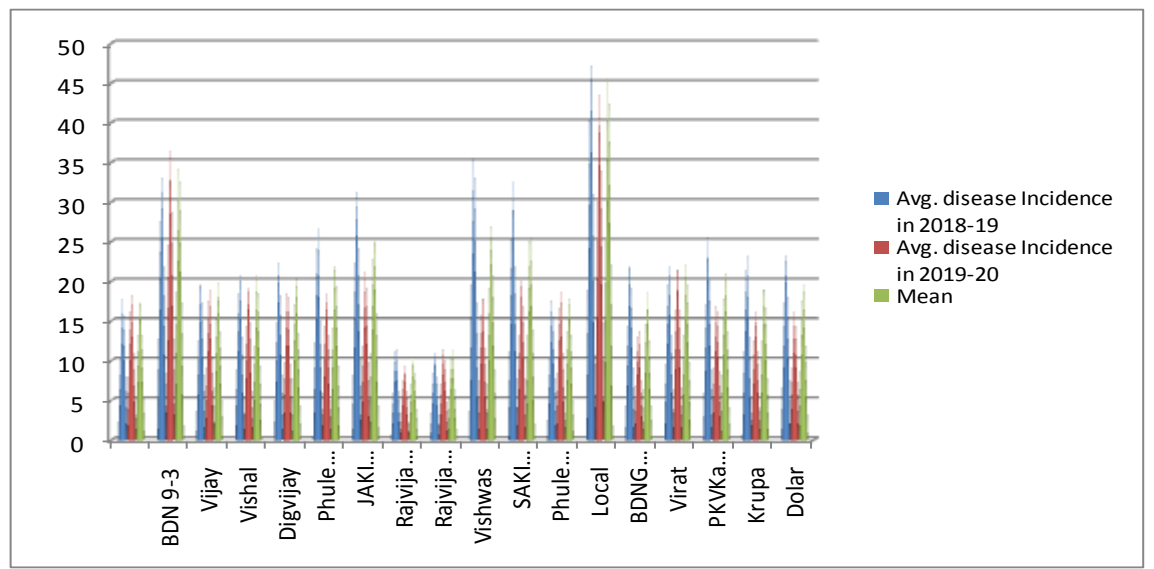

Agro-climatic zone wise disease incidence of chickpea wilt in Marathwada region of Maharashtra

The date presented in Table 2 revealed that chickpea wilt disease incidence was found maximum in Moderate rainfall zone (29.28 and $30.60 \%)$ followed by Assured rainfall zone (25.12 and $26.18 \%$ ) respectively, during Rabi 2018-19 and 2019-20. However, minimum disease incidence was recorded in Scarcity zone (19.36 and $22.11 \%$ ) during Rabi 2018-19 and 2019-20.
Variety wise incidence of Chickpea wilt in agro climatic zones of Marathwada region

Result (Table 3 and Fig. 3) revealed that maximum chickpea wilt disease incidence was found on Local variety (49.00 and 44.00 $\%)$ during Rabi, 2018-19 and 201920respectively, followed by Phule G-5 (36.25\%), BDN 9-3 (34.00\%), SAKI 9516 $(32.50 \%)$, JAKI $9218(32.00 \%)$ and minimum wilt disease incidence was found in variety Rajvijay 203 (11.33 \%) during Rabi 2018-19. While during Rabi 2019-20, 
maximum chickpea wilt disease incidence was found in BDN 9-3 (36.67 \%) followed by Phule G 95418 (22.60\%), JAKI 9218(21.25 $\%)$, SAKI $9516(20.83 \%)$ and minimum wilt disease incidence was found in variety Rajvijay 202 (9.33 \%) during Rabi 2019-20.

The results (Fig. 3) revealed that pooled per cent mean incidence of chickpea wilt during Rabi, 2018-19 and 2019-20 was recorded maximum on Local variety $(46.50 \%)$ followed by BDN 9-3 (35.34 \%) and Vishwas (27.50\%), whereas, it was minimum on Rajvijay 202 (10.61\%) and Rajvijay 203 (11.50\%).

These results obtained in the present studies on occurrence, distribution, yield loss and survey of chickpea wilt caused by Fusarium oxysporum f.sp. ciceri are similar to those reported earlier by several workers on chickpea and other crops.

Studies carried by Ghosh et al., (2013) on survey during Rabi2010-2011 to find information on the occurrence and distribution chickpea diseases in respect to soil type, cultivar, seed treatment in central and Southern parts of India. It was revealed that local cultivars transcendent in most farmer's fields ( 25 to $48 \%$ ), whereas, $63 \%$ of the farmers were practices seed treatment with fungicide and reported the incidence of chickpea wilt disease ranged from 9.7 to 13.8 $\%$. Nikam et al., (2011) conducted survey on chickpea wilt in Tashils of Latur district and described the average wilt incidence to the tune of $12.26 \%$ with maximum wilt incidence was found in Ausa (15.4\%).

Aforesaid variation in wilt incidence and wide spread nature of disease have been reported by earlier worker like Nema and Khare (1973), Trapero-Casas and Jimenez-diaz (1985), Jalali and Chand (1992),Navas-Cortes et al., (2000), Reddy (2002), Jadhav et al.,
(2006), Pitambar et al., (2010), Abera et al., (2011), Jendoubi et al.(2017), Singh et al.(2017), Mulekar et al., (2017), V. Govardhan Rao et al., (2019) and Yimer et al., (2018).

\section{References}

Abera, M., Sakhuja, P. K., Fininsa and Seid A. (2011) Status of chickpea Fusarium wilt (Fusarium oxysporum f.sp. ciceri) in northwestern Ethiopia. Archives of Phytopathology and Plant Protection Vol. 44, No. 13, August 2011, 12611272.

Chaudhry, M. A., llyas, M. B., Muhammad, F. and Ghazanfar. M. U. (2007). Sources of resistance in Chickpea germplasm against Fusarium wilt. Mycopath. 5(1): 17-21.

Chaudhry, M.A., Ilyas, M.B., Muhammad, F. and Ghazanfar, M.U. 2007. Sources of resistance in chickpea germplasm against Fusarium wilt. Mycopath, 5(1): 17-21.

Dubey, S. C., Singh S. R. and Singh B. (2010). Morphological and pathogenic variability of Indian isolates of Fusarium oxysporum f. sp. cicerica using chickpea wilt. Archives of Phytopathology and Plant Protection Vol. 43 (2): 174-190.

Ghosh R., Sharma, M., Telangre, R. and Pande, S. (2013).Occurrence and Distribution of Chickpea Diseases in Central and Southern Parts of India. American J. Pl. Sci. Vol. 04 : 940-944.

Gupta, S.K., Upadhyay, J.P. and Ojha, K.H. (1997). Effect of fungicidal seed treatment on the incidence of chickpea wilt complex. Ann. Pl. Prot. Sci.5: 184187.

Halila, M. H. and Strange, R. N. (1996). Identification of the causal agent of wilt of chickpea in Tunisia as $F$. oxysporum f. sp. ciceris race 0. Phytopathologia 
Mediterranean. 35: 67-74.

Jadhav V.T., C.V. Ambadkar and N.H. Kadam (2006) Biological management of wilt of Chick pea. P.K.V. Res. J., 30 (2) : 253-254.

Jalali, B. L and Chand, H. (1992). Chickpea wilt. Pl Dise. Of InterlImp. Diseases of Cereals and Pulses. Prentice Hall, Englewood Cliffs,New Jersey. 1: 429444.

Jendoubi, W., Bouhadida, M., Boukteb, A., Beji M. and Kharrat, M. (2017). Fusarium Wilt Affecting Chickpea Crop. Agriculture, 7, 23: 2-16.

Kumar, S. and Bourai, V. A. (2012).Economic analysis of pulses production their benefits and constraints (a case study of sample villages of Assan valley of Uttarakhand, India). J. Hu. Social Sci. 4(1): 41-53.

Mayee, C.D. and Datar,V.V.(1986). Phytopathometry, Marathwada Agricultural University, Parbhani, pp.146.

V. G. Mulekar, A. G. Desai and C. V. Ambadkar (2017). Influence of hydrogen-ion concentration on variability in Fusarium oxysporum f. sp. ricini causing wilt of castor. Multilogic in Science, 7 (23): 67-70.

Navas-Cortés, J.A., Hau.B.and Jiménez-Díaz, R.M. (2000). Yield loss in chickpeas in relation to development of Fusarium wilt epidemics. Phytopathology 90: 1269-1278.

Nema K.G. and Khare M.N. (1973).A conspectus of wilt of Bengal gram in Madhya Pradesh.Symposium on wilt problem and breeding for wilt resistance in Bengal gram sept.1973, at IARI, New Delhi, India. p 4

Nene, Y. L., Shelia, V. K and Sharma, S. B. (1984). A world list of chickpea (Cicerarietinum L.) and pigeonpea (Cajanuscajan (L.) Millsp.) pathogens.
ICRISAT Pulse Pathology Progress Report 32, pp. 19.

Nene, Y. L., Shelia, V. K and Sharma, S. B. (1996).A world list of chickpea and Pigeon pea pathogens 5th Edn. Patancheru, Andhra Pradesh, India. ICRISAT.pp, 1- 28.

Nikam, P. S., Jagtap, G. P. and Sontakke, P. L. (2011).Survey, surveillance and cultural characteristics of chickpea wilt caused by Fusarium oxysporium f. sp. ciceri. Afr. J. Agric. Res. 6(7): 19131917.

Pitambar, N., Jibhakate, M. K., Mondhe and Mate, G. D. (2010).Assessment of wilt complex in chickpea crop at Nagpur district.J.Pl.Dis.Sci. Vol. 5(1): 251-253.

Reddy, Y. S. (2002). Studies on wilt complex of chickpea (Cicer arientinum L.). M. Sc. (Agri.) thesis, I.G.N.U., Raipur (CG), India.

Govardhan Rao, V., D.N. Dhutraj, S.R. Bhalerao, K.T. Apet, C.V. Ambadkar, B. Prasanna Kumar, A. T. Daunde, P.L. Sontakke and A.G. Patil (2019) Investigation of Genetic Diversity in Fusarium Wilt of Egg Plant Caused by Fusarium oxysporumf.Sp. melangene (Schlecht) Mutuo and Ishigami in Marathwada Region of Maharastra, India. Int.J.Curr.Microbiol.App.Sci, 8(7): 1079-1093

Singh, D. and Simon, S. (2017). Bio control potential of Pseudomonas fluorescens against Fusarium wilt of chickpea. Prog. Agric. Vol. 17(1):47-51.

Singh, G., Chen, W., Rubiales, D., Moore, K., Sharma, Y. R. and Gan, Y. (2007).Diseases and their management.In Chickpea Breeding and Management. (Eds. Yadav, Redden, Chen and Sharma) $C A B$ International. pp. 497-519.

Sunkad, G., Deepa, H., Shruthi, T.H. and Dinesh Singh. (2019). Chickpea wilt: status, diagnostics and 
management. Indian

Phytopathology 72, 619-627.

Trapero-casas, A. and Jimenez-Diaz, R.M.

(1985). Fungal wilt and root rot disease

of chickpea in southern Spain. Phytopathology, 75: 1146-1151.

Venkataramanamma, K., Reddy, B.V. Jayalakshmi, R. B., Jayalakshmi, V. S., Hari Prasad K.V., and Naidu, M. G. (2018): Screening of chickpea germplasm / genotypes against
Fusarium wilt of chickpea under field and artificial condition. Int.J.Curr. Microbiol.App.Sci. 7 (9): 1041-1050.

Yimer, S.M., Ahmed, S., Fininsac, C., Tadessed, N., Hamwiehe, A. and Douglas R. Cookf. (2018) .Distribution and factors influencing chickpea wilt and root rot epidemics in Ethiopia Crop Protection $106: 150-155$.

\section{How to cite this article:}

Sontakke, P. L., D. N. Dhutraj, C. V. Ambadkar and Badgujar, S. L. 2020. Status of Chickpea Wilt caused by Fusarium oxysporum f. sp. ciceri in Marathwada Region of Maharashtra State. Int.J.Curr.Microbiol.App.Sci. 9(07): 2553-2560. doi: https://doi.org/10.20546/ijcmas.2020.907.300 